\title{
Una dictadura para los niños. Las conmemoraciones del 24 de marzo en escuelas primarias de la provincia de Buenos Aires y la influencia de las revistas de EDIBA
}

por Gonzalo de Amézola

(IdHICS-CONICET / Universidad Nacional de La Plata; Universidad Nacional de Quilmes) y Claudia D'Achary, Universidad Nacional de General Sarmiento, Argentina. gonzalodeamezola@gmail.com; claudiadachary@yahoo.com.ar

Recibido: 03|04|2013 - Aceptado: 22|04|2013

\section{Resumen}

Este trabajo se ocupa de las conmemoraciones realizadas en escuelas primarias públicas de Malvinas Argentinas, en el Conurbano Bonaerense, para el Día de la Memoria en un lapso que abarca de 2008 a 2013. Se indaga sobre la influencia ejercida sobre esos rituales por las publicaciones de la Editorial Bahiense dirigidas a los docentes y las representaciones que proponen sobre la última dictadura militar..

\section{Palabras clave}

Día de la Memoria, escuela primaria, dictadura militar, maestra de Primer Ciclo.

co

\section{A dictatorship for children. The commemorations of the March 24 primary} schools in the province of Buenos Aires and the influence of magazines Ediba

\section{Abstract}

This paper deals with the celebrations performed in public elementary schools Malvinas Argentinas in Buenos Aires conurbation, for Memorial Day in a period spanning from 2008 to 20I3. It investigates the influence on these rituals by the Editorial Bahiense publications directed at teachers and proposed representations about the last military dictatorship.

\section{Keywords}

Day of Remembrance, elementary school, military dictatorship, maestra de Primer Ciclo. 